\title{
Smart Application using Biometric and RFID for Ration Card
}

\author{
Chetan S. Kandare \\ University of Pune \\ BVCOE \& RI Nasik \\ Trimbakeshwar Nasik
}

\author{
Vaishali R. Tribhuvan \\ University of Pune \\ BVCOE \& RI Nasik \\ Trimbakeshwar Nasik
}

\author{
Kalyani R. Kothawade \\ University Of Pune \\ BVCOE \& RI Nasik \\ Trimbakeshwar Nasik
}

\author{
K. S. Kumavat \\ Professor \\ Internal Guide of Computer Department ENGG \\ BVCOE \& RI NASIK \\ Trimbakeshwar Nasik
}

\begin{abstract}
A Smart System and Application for ration card contain Biometric and Radio Frequency Identification (RFID). To preventing the ration forgery as there are chances that the shopkeeper my sell the material to someone else and take the profit and put something false recodes in system. In smart ration system, RFID tag act as ration card and all details of ration holder and there family member is stored in RFID Tag. RFID reader is used for reading RFID tag and user verification. The microcontroller connected to the reader will checks for the user authentication. If the user is found authentic then the quantity of ration to be given to the customer according to the total number of family members will be displayed on display device. A smart system is free from thieves. Delivered ration details directly send through web application to the government of india without any manual feeding and also sending message to customer's register mobile number and ration receipt.
\end{abstract}

\section{Keywords}

RFID Tag, RFID Reader, Biometric, Thumb scanner

\section{INTRODUCTION}

In India ration card firstly introducing in world war II. The aim of India government to provides foods like wheat, rice , sugar and kerosene to Indian citizen in cheapest rate. There are many types of ration card in India that's issued to ration holder according it's income. Ration card is most important document in India because ration card can be used as identity proof and Ration card is needed when you apply for passport, PAN number, driving license etc Ration Card is needed when you applying for adhar card, passport, PAN and driving licenses so ration card is mandatory document in India. But now today's generation forgot actual used of ration card they used ration card id proof and they don't get any facility from Indian government.

Current ration card system having many drawbacks they are listed in below.

1. User does not know when ration is come and gone.

2. If the items are not sold up to the last of the month, then the shopkeeper will sell it to someone else and take the profit into his pocket

3. Depending on manual recodes like ration diary.
4. Does not provide any kind of security.

So to avoid this drawback we are moving to smart application using Biometric and RFID for ration card.

Every customer has given a RFID tag which acts as the ration card. This RFID tags has all the information of the customer, needed for taking the ration from the ration shops. The customer has to show this RFID tag to the RFID reader, which is attached to a microcontroller, which reads the information in the tag and accordingly instruct the shopkeeper to give this much amount of ration to that card holder. Then the GSM is used to send the information of ration taken to the government and also to the customer. Radio Frequency Identification (RFID) is the wireless technology to read electromagnetic fields of the radio frequency. The basic purpose to use RFID is to automatically identify and track the attached electromagnetic tag. RFID used in this paper is RKI1512.This module directly connects to any microcontroller UART or through a RS232 converter to PC. It gives UART/Wiegand26 output. This RFID Reader Module works with any $125 \mathrm{KHz}$ RFID tags. Global System for Mobile Communication (GSM) is a European Telecommunication standard which is used to define the protocols of second generation. In this paper, we use GSM 900A. This GSM works on $12 \mathrm{~V}, 1 \mathrm{~A}$ dc source.

\section{LITERATURE SURVEY}

\subsection{Smart Ration Card}

This paper proposes the improvised technique of implementing smart ration card. The main objectives of smart ration card are providing food grains and other essential items to vulnerable sections of the society at reasonable (subsidized) prices and to eradicate inefficiency in the targeting of beneficiaries and the resulting leakage of subsidies which is the main disadvantage of the present PDS (Public Distribution System) [1].

\subsection{Smart Ration Card Using RFID and GSM Technique}

In this paper developed a smart ration card using Radio Frequency Identification (RFID) technique to prevent the ration forgery as there are chances that the shopkeeper may sell the material to someone else and take profit and put some false amount in their records. In this system, a RFID tag 
is used that carries the family member details and the customer needs to show this tag to the RFID reader [3].

\subsection{RFID and GSM based Automatic Rationing System using LPC2148}

The proposed system replaces the manual work in ration shop. The main objective of the designed system is the automation of ration shop to provide transparency. The proposed automatic ration shop for public distribution system is based on Radio Frequency Identification (RFID) technology that replaces conventional ration cards. The RFID tags are provided instead of conventional ration cards [2].

\subsection{Smart Ration Distribution \& Controlling}

This paper implements a simple PDA device (personal data assistant) with RFID tag used as an e-ration card in place of a conventional ration card.[4]

\section{SYSTEM OVERVIEW}

\subsection{System Architecture}

Figure 1 show system architecture for smart ration card system. Smart ration card system contain three module ration shop, ration card generation officer and district level and taluka level application. Ration shop is worked as distributor for ration which contain ration delivery, scanning of RFID and customer thumb impression and ration collection. Ration card generation officer work as a middleware for ration shop and database of customer stored at district level. It contained ration card creation, enrollment of RFID and thumb and also having rights to add or remove members. District level or taluka level application contain information about adding user and to distribute ration. All three modules are connected to database using MySQL and embedded module RFID reader and thumb scanner.

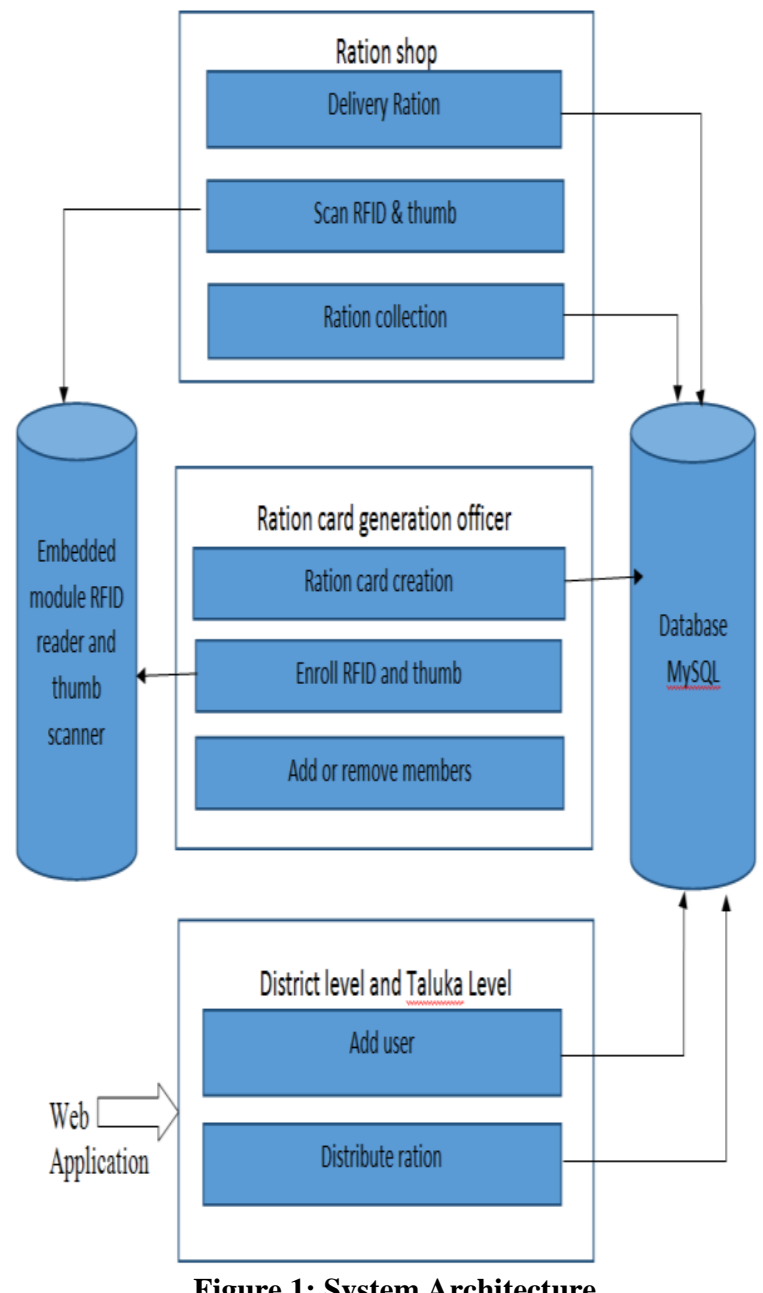

Figure 1: System Architecture

\subsection{System Flow}

Figure 2 shows the system working using system flow diagram. Whenever application is started first step is to scan RFID card using RFID receiver. It will send a unique number via serial out to the controller. Then database will compare that number to check whether match fount or not. If it does not match then flow will send to the start otherwise display value on GUI screen. After that using GSM the transaction information is send and updated information on web. If transaction is done successfully then process is completed and ration is distributed. Also alert message is send to the user as well as taluka and district level application. If transaction is not done properly then again the transaction process is started. 


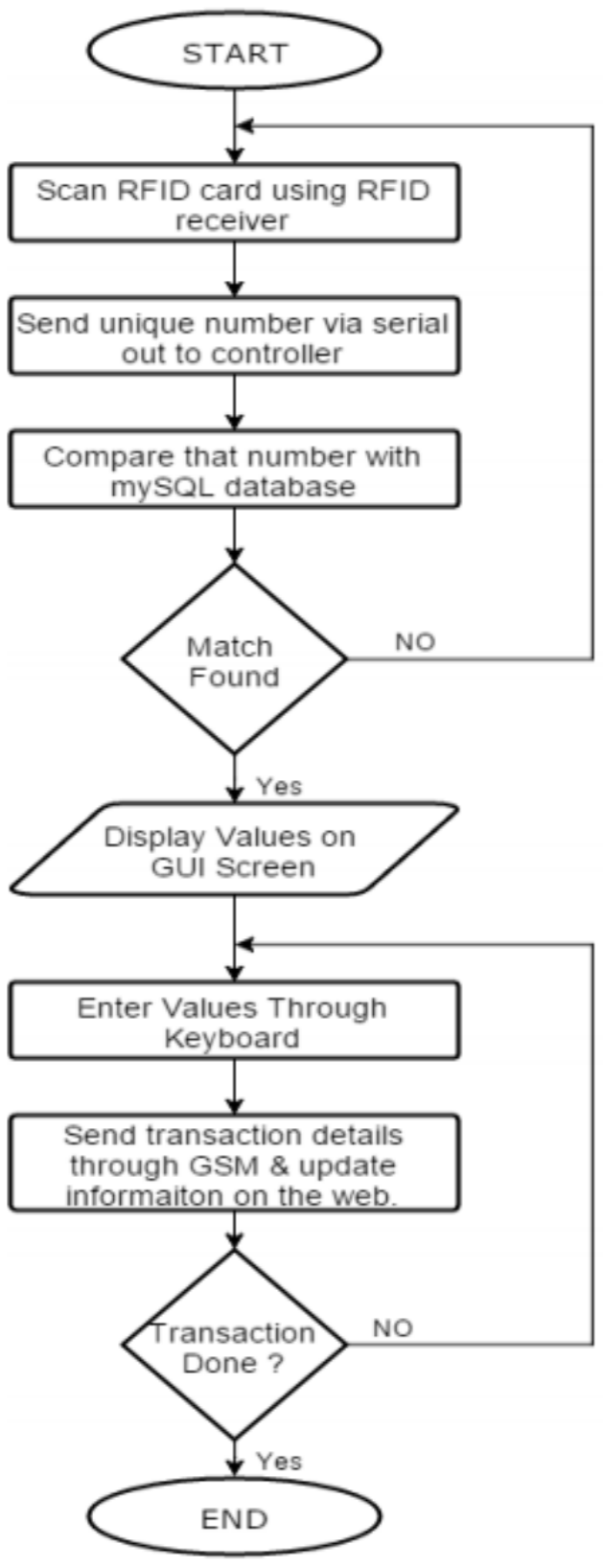

Figure 2: System Flow

\section{ALGORITHAM}

\subsection{AES algorithm}

The Advanced Encryption Standard or AES is a symmetric block cipher used protect classified information and is implemented in software and hardware throughout the world to encrypt sensitive data.The AES algorithm is symmetric key algorithm which means the same key is used to both encrypt and decrypt message.Also the cipher text produced by the AES algorithm is the same size as the plain text message.

The features of AES are as follows

- Symmetric key symmetric block cipher

- 128-bit data, 128/192/256-bit keys
- Stronger and faster than Triple-DES

- $\quad$ Provide full specification and design details

- Software implementable in C and Java

\subsection{SHA algorithm}

Used to keep data secure. Hashing function is one of the most commonly used encryption method. Hash is special mathematical function that performs one way encryption. Its input process data is 512 bit block.

\section{CONCLUSION}

The smart system is more secure and transparent than the normal existing system. Influence of fraud data entry in the ration database can be maintained simply with the use of this smart ration card system. Customer can be authenticated using RFID swapping and thumb detection. It is expected that the proposed system will be more transparent, reliable than the existing ration card system.

\section{REFERENCES}

[1] Vikram Singh. "Smart Ration Card", Journal of Global Research in Computer Science. Volume 4, Issue No 4, April 2013

[2] Vinayak T. Shelar, Mahadev S. Patil "RFID and GSM based Automatic Rationing System using LPC2148", International Journal of Advanced Research in Computer Engineering \& Technology. Volume 4 Issue 6, June 2015

[3] Diksha Kamble, Bharati Lokhande, Prachiti Sardar, Tushar Khose "Smart Ration card system using RFID and Biometrics", International Journal of Engineering and Computer Science. Volume 5 Issue 12 Dec. 2016

[4] Kashinath Wakade, Pankaj Chidrawar, Dinesh Aitwade "Smart Ration Distribution and Controlling",International Journal of Scientific and Research Publications, Volume 5, Issue 4, April 2015.

\section{AUTHOR'S PROFILE}

Chetan S. Kandare he is Engineering student of Computer Engineering at Brahma Valley College of Engineering And Research Institute, Nasik under University of Pune.

Kalyani R. Kothawade she is Engineering student of Computer Engineering at Brahma Valley College of Engineering And Research Institute, Nasik under University of Pune.

Vaishali R. Tribhuvan she is Engineering student of Computer Engineering at Brahma Valley College of Engineering And Research Institute, Nasik under University of Pune.

Prof .K. S. Kumavat, Ph.D pursuing under Mumbai University, ME, BE Computer Engg. was educated at Pune University. Presently she is working as a Assistant Professor in Computer Department of Brahma Valley College of Engineering and Research Institute, Nasik, Maharashtra, India. 